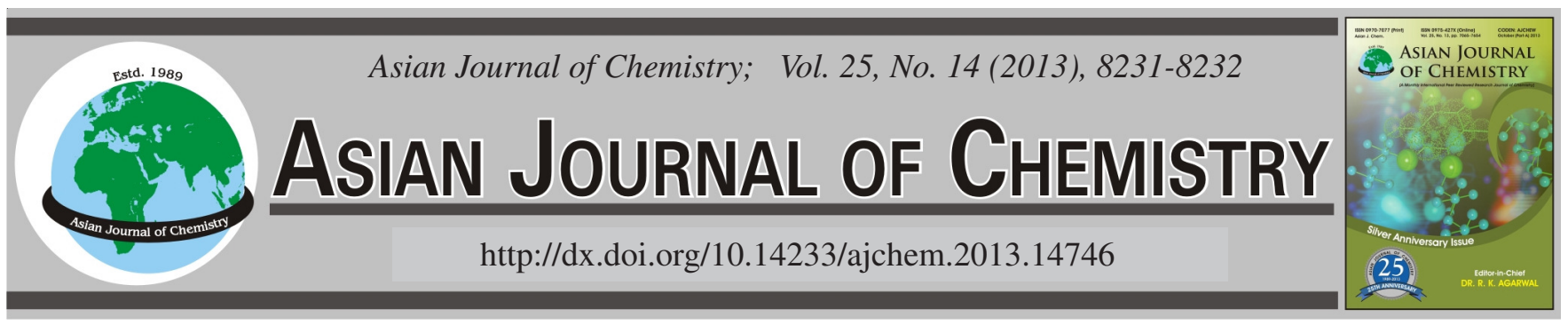

NOTE

\title{
Analysis of Macroelements, Beneficial Trace Elements, Rare Earth Elements in the Wild Ixeris Chinensis (Thunb.) Nakai by ICP-MS
}

\section{YukUi Rui}

College of Resources and Environmental Sciences, China Agricultural University, Beijing 100193, P.R. China

Corresponding author: E-mail: ruiyukui@163.com

(Received: 30 October 2012;

Accepted: 12 August 2013)

AJC-13918

\begin{abstract}
Wild China Ixeris [Ixeris chinensis (Thunb.) Nakai] has Chinese herbal properties and can be used for the treatment for many diseases. But trace element nutrition in wild China Ixeris has not been reported, including heavy metals, beneficial elements for human health and rare earth elements. The results showed that the concentrations of macrolements and beneficial trace elements in wild China Ixeris are many times higher than those in most vegetables, such as radish, cucumber, garland chrysanthemum, parsley, chives and leek moss, so wild China Ixeris is of great significance to complement macrolements and beneficial trace elements for the human health. Rare earth elements in wild China Ixeris are at a low level. Some heavy metals in wild China Ixeris exceeded the national standard, so before eating the harmful elements in wild China Ixeris should be detected.
\end{abstract}

Key Words: Ixeris chinensis (Thunb.) Nakai, Trace elements, Heavy metals, ICP-MS.

ᄂ - - - - - - - - - - - - - - - - - - - - - - - - - -

Wild China Ixeris [Ixeris chinensis (Thunb.) Nakai], also called bitter herbs, section prop lotus, the small bitter wheat dish, bitter leaf seedlings, Patrina Ma bitter vegetables, ground squirrel grass, small endive, blood circulation grass trap blood Dan, a small the Kumai, bitter small dishes Kudiezi light leaves Lactuca, Yan'er clothing and Patrinia grass. Wild China Ixeris grows in the mountain wilderness and often as field weeds. Wild China Ixeris is located in the northern, eastern and southern of China. Wild China Ixeris belongs to Lactuca genus of Compositae ${ }^{1}$.

Wild China Ixeris has Chinese herbal properties of detoxification, cooling consumption carbuncle abscess, stasis and relieve pain, which can be used for the treatment for appendicitis, lung carbuncle high fever, cough vomiting blood and pus, heat canker boil furuncle pain swelling, chest and abdominal pain, appendicitis, enteritis, dysentery, postpartum abdominal pain, dysmenorrhea, etc. ${ }^{1}$.

Aboveground part of wild China Ixeris contains Sonchus glycosides A, B, C and D, glucoza-luzanin C, macroliniside A, crepidiaside A and picriside) $\mathrm{B}, \mathrm{C}$; also contains cinaroside, hyperoside, linarin, apigenin, quercetin and kaempferol; likewise luteolin, quercimeritrin, isocynaroside, 7- $\beta$-Dglucuronopyranoside. Seed oil of wild China Ixeris contains $13.7 \%$ vernolicacid. Leaf of wild China Ixeris contains vitamin $\mathrm{C}^{1,2}$.
Trace element nutrition in wild China Ixeris has not been reported, including heavy metals, beneficial elements for human health and rare earth elements. The goal of this work is to study the nutritional and safety characteristics of elements to provide basis of food development of wild China Ixeris.

Wild China Ixeris [Ixeris chinensis (Thunb.) Nakai] were collected from Huairou district of Beijing city. The samples were washed with deionized water, grinded, digested concentrated nitric acid and $30 \% \mathrm{H}_{2} \mathrm{O}_{2}$ solution, finally determined by ICP-MS, the ICP-MS instrument is Thermo-X7 produced by Thermo Electron Corporation of USA.

Macroelements in wild China Ixeris: The results show that wild China Ixeris contain much $\mathrm{Mg}, \mathrm{P}, \mathrm{K}, \mathrm{Ca}$ and $\mathrm{Mn}$ (Table-1), whose concentrations are many times higher than those in vegetables radish, cucumber, garland chrysanthemum, parsley, chives and leek moss, so wild China Ixeris is of great significance to complement the macroelements in the human body $^{3}$. The results are consistent to the former results ${ }^{4}$.

Beneficial trace elements in wild China Ixeris: In beneficial trace elements, content of $\mathrm{Zn}$ in wild China Ixeris is much higher than that in vegetables radish, cucumber, garland chrysanthemum, parsley, chives, leek moss, so wild China Ixeris can supplement $\mathrm{Zn}$ for human body. In addition to zinc, the wild China Ixeris also contain many other beneficial trace elements, such as I, Se, Mo, Sr, Rb, Li and Co (Table-2), which are few reported in leafy vegetables. The descending order of 


\begin{tabular}{cc|cc}
\hline \multicolumn{4}{c}{ TABLE-1 } \\
CONCENTRATIONS OF SEVEN KINDS OF \\
\multicolumn{4}{c}{ MACROELEMENTS IN WILD CHINA IXERIS (ng/g) } \\
\hline Elements & Concentration & Elements & Concentration \\
\hline $\mathrm{Mg}$ & 1640115.41 & $\mathrm{Ca}$ & 8094053.76 \\
$\mathrm{Si}$ & 178976.32 & $\mathrm{Mn}$ & 31012.69 \\
$\mathrm{P}$ & 4475560.05 & $\mathrm{Fe}$ & 133069.54 \\
$\mathrm{~K}$ & 12133185.95 & - & - \\
\hline
\end{tabular}

TABLE-2

CONCENTRATIONS OF EIGHT KINDS OF BENEFICIAL TRACE ELEMENTS IN WILD CHINA IXERIS (ng/g)

\begin{tabular}{cc|cc}
\hline Elements & Concentration & Elements & Concentration \\
\hline $\mathrm{Li}$ & 959.73 & $\mathrm{Se}$ & 884.79 \\
$\mathrm{I}$ & 1376.40 & $\mathrm{Rb}$ & 2678.36 \\
$\mathrm{Co}$ & 112.91 & $\mathrm{Sr}$ & 25293.27 \\
$\mathrm{Zn}$ & 21643.69 & $\mathrm{Mo}$ & 593.03 \\
\hline
\end{tabular}

beneficial trace elements in wild China Ixeris is $\mathrm{Sr}>\mathrm{Zn}>\mathrm{Rb}$ $>\mathrm{I}>\mathrm{Li}>\mathrm{Se}>\mathrm{Mo}>\mathrm{Co}$.

Harmful trace elements in wild China Ixeris: Heavy metals and harmful elements, as important indicators of food safety, were also determined in wild China Ixeris. The results showed that wild China Ixeris contained much $\mathrm{Pb}, \mathrm{Al}, \mathrm{Cu}$ and $\mathrm{Ni}$, compared with national standards (GB 2762-2005), Pb, As in wild China Ixeris exceeded the national standard and the contents of $\mathrm{Cd}, \mathrm{Cr}, \mathrm{Hg}$ were lower than national standard, which should be relative to the heavy metals content in soil and growth cycle of wild vegetable. So before eating the harmful elements in wild China Ixeris should be detected ${ }^{5}$. In addition to heavy metals in standards, $\mathrm{Al}, \mathrm{Ti}, \mathrm{Cu}$ content in wild China Ixeris are also very high (Table-3), which also should arouse our attention.

TABLE-3

CONCENTRATIONS OF TWELVE KINDS OF HARMFUL TRACE ELEMENTS IN WILD CHINA IXERIS (ng/g)

\begin{tabular}{cc|cc}
\hline Elements & Concentration & Elements & Concentration \\
\hline $\mathrm{Al}$ & 90564.05 & $\mathrm{Hg}$ & 0.00 \\
$\mathrm{~V}$ & 287.27 & $\mathrm{Tl}$ & 7.99 \\
$\mathrm{Cr}$ & 280.78 & $\mathrm{~Pb}$ & 443.15 \\
$\mathrm{Ni}$ & 794.86 & $\mathrm{Cd}$ & 179.36 \\
$\mathrm{Cu}$ & 8892.89 & $\mathrm{Sn}$ & 24.98 \\
$\mathrm{As}$ & 70.44 & $\mathrm{Sb}$ & 16.49 \\
\hline
\end{tabular}

Rare earth elements in wild China Ixeris: Rare earth elements in food have been reported the last several years, most researches proved that the trace rare earth elements were beneficial to humans, but too much rare earth elements were harmful $^{6,7}$. The results in this study proved that rare earth elements in wild China Ixeris are at a low level (Table-4).

Other trace elements whose biological function are unknown in wild China Ixeris: This experiment also determined the other elements in wild China Ixeris, including Be, $\mathrm{Ga}, \mathrm{Ge}, \mathrm{Ti}, \mathrm{Br}, \mathrm{Nb}, \mathrm{Cs}, \mathrm{Ba}, \mathrm{W}, \mathrm{Os}, \mathrm{Au}, \mathrm{Rh}, \mathrm{Pd}, \mathrm{Bi}$, Th and U (Table-5). Although there is no direct evidence that these elements are related to human health and disease, we hope that these data can provide basal data for the future development of the wild China Ixeris.

\begin{tabular}{cc|cc}
\multicolumn{4}{c}{ TABLE-4 } \\
\multicolumn{4}{c}{ CONCENTRATIONS OF RARE EARTH } \\
ELEMENTS IN WILD CHINA IXERIS (ng/g) \\
\hline Elements & Concentration & Elements & Concentration \\
\hline $\mathrm{La}$ & 78.44 & $\mathrm{Dy}$ & 9.49 \\
$\mathrm{Ce}$ & 168.86 & $\mathrm{Ho}$ & 2.00 \\
$\mathrm{Pr}$ & 19.48 & $\mathrm{Er}$ & 3.00 \\
$\mathrm{Nd}$ & 71.44 & $\mathrm{Tm}$ & 0.50 \\
$\mathrm{Sm}$ & 14.99 & $\mathrm{Yb}$ & 2.00 \\
$\mathrm{Eu}$ & 6.49 & $\mathrm{Lu}$ & 1.00 \\
$\mathrm{Gd}$ & 10.99 & $\mathrm{Sc}$ & 112.41 \\
$\mathrm{~Tb}$ & 2.50 & $\mathrm{Y}$ & 37.47 \\
\hline
\end{tabular}

\begin{tabular}{cc|cc}
\multicolumn{4}{c}{ TABLE-5 } \\
CONCENTRATIONS OF OTHER TRACE ELEMENTS \\
WHOSE BIOLOGICAL FUNCTION ARE UNKNOWN \\
IN WILD CHINA IXERIS (ng/g) \\
\hline Elements & Concentration & Elements & Concentration \\
\hline $\mathrm{Be}$ & 5.00 & $\mathrm{~W}$ & 28.48 \\
$\mathrm{Ga}$ & 46.46 & $\mathrm{Os}$ & 0.50 \\
$\mathrm{Ge}$ & 0.50 & $\mathrm{Au}$ & 1.00 \\
$\mathrm{Ti}$ & 21786.07 & $\mathrm{Rh}$ & 29.48 \\
$\mathrm{Br}$ & 2066.35 & $\mathrm{Pd}$ & 2.50 \\
$\mathrm{Nb}$ & 14.49 & $\mathrm{Bi}$ & 9.49 \\
$\mathrm{Cs}$ & 23.48 & $\mathrm{Th}$ & 22.98 \\
$\mathrm{Ba}$ & 30235.81 & $\mathrm{U}$ & 8.49 \\
\hline
\end{tabular}

\section{Conclusion}

(i) The concentrations of macrolements and beneficial trace elements in wild China are many times higher than those in most vegetables, such as radish, cucumber, garland chrysanthemum, parsley, chives and leek moss, so wild China Ixeris is of great significance to complement macrolements and beneficial trace elements for the human health.

(ii) Rare earth elements in wild China Ixeris are at a low level.

(iii) Some heavy metals in wild China Ixeris exceeded the national standard, so before eating the harmful elements in wild China Ixeris should be detected.

\section{ACKNOWLEDGEMENTS}

The project was supported by the Key National Natural Science Foundation of China (No.41130526) and Chinese Universities Scientific Fund (Project No. 2011JS161). We thank Ms. Ouyang Li, Ms. Yan Lailai, Ms. Liu Yaqiong and Prof. Wang Jingyu (Peiking University, China) for their assistance.

\section{REFERENCES}

1. http://baike.baidu.com/view/30711.htm.

2. J.J. Zhu and G.Q. He, Food Sci., 23, 113 (2002).

3. Q.P. Long, Studies Trace Elements Health, 24, 32 (2007).

4. N.X. Wang, X.G. Cui, A.Q. Du and H.Z. Mao, Spectrosc. Spectral Anal., 27, 1229 (2007).

5. National standards of P.R. of China, Maximum Levels of Contaminants in Foods, GB 2762 (2005).

6. Y. Li, J.L. Yang and Y. Jiang, J. Agric. Food Chem., 60, 3033 (2012).

7. M.L. He, U. Wehr and W.A. Rambeck, J. Animal Physiol. Animal Nutr., 94, 86 (2010). 